\title{
14. Bibles, Baseball and Butterfly Sleeves: Filipina Women and American Protestant Missions, 1900-1930
}

\author{
Laura R. Prieto \\ Simmons College
}

\section{Introduction}

Sometime before April in 1922, a group of women in Mindanao posed for a photograph. Two of them had come to the Philippines as missionaries from the United States. Four were Filipinas associated with the mission. It is difficult to image what occasion befits the range of clothing they wear. The Filipina women's choice of fine attire - the elegant terno - denotes a formal celebration; ${ }^{1}$ yet the youngest of them is dressed more casually and a la americana. The American women are all in white, one in almost the exact pattern of dress as the young Filipina, the other with a nurse's cap and uniform. Some eye the photographer warily, letting uncertainty or impatience or weariness show in their expressions. One of the missionaries twists her foot sideways. The painted backdrop is standard for a studio, but here its awkward distance behind the group creates the impression that these women are on stage. They seem selfconscious and unsure what we may make of their performance (Figure 31).

Gently but eagerly turning over the image in anticipation of a full caption, one meets with disappointment. The occasion is unidentified. What is pencilled on the back of the photograph reads only: "Miss Anna Fox and Miss Florence Fox with girls, Cagayan, Philippine Islands, 1924." ${ }^{2}$ The date is certainly wrong, since Life and Light, a monthly magazine published by the Congregational Woman's Board of Missions, used it as the frontispiece of their September 1922 issue.

\footnotetext{
1 Scholars vary in the grammatical point of whether one should use the feminine form 'Filipina' as an adjective in English language writing. In this essay I deliberately employ the gendered Spanish-derived language as a feminist practice to emphasise the significance of gender in the representation and identities under analysis here.

2 The "Cagayan" to which these missionaries referred is a city in northern Mindanao, also known as Cagayan de Oro. It is distinct from the province Cagayan in Northern Luzon. This chapter replicates the historical subjects' usage of simply Cagayan. I use the contemporary name "Cagayan" throughout the main text in order to preserve what I regard as contextual historical authenticity.
} 
The anonymous caption writer did not know any of the subjects well, for everyone called "Anna Fox" by her middle name, "Isabel." The names of the other women - the Filipinas — are not noted at all; they are simply, collectively "girls."

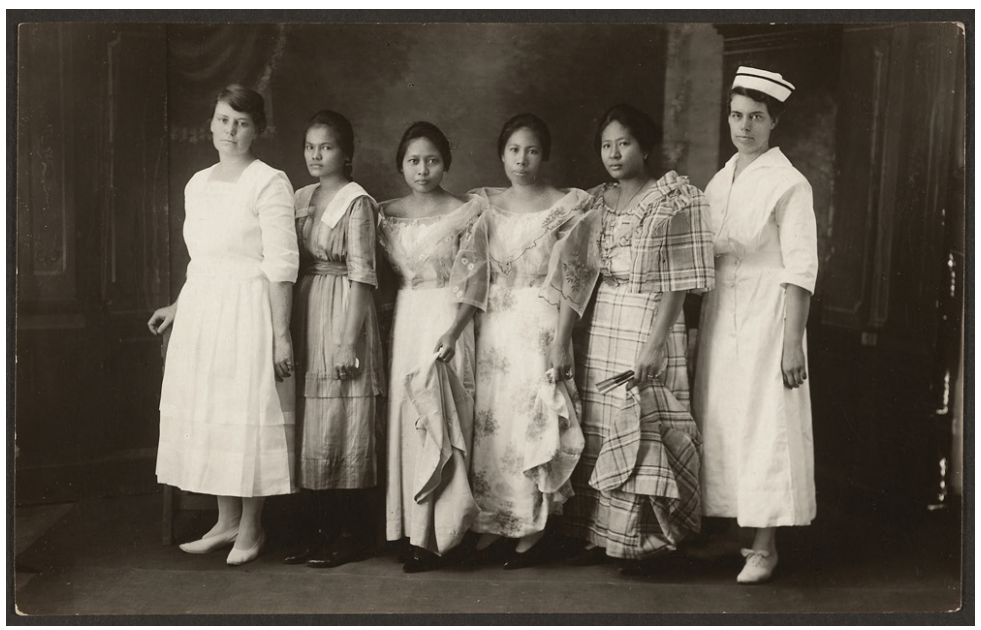

Figure 31. Anna Isabel Fox, unnamed Bible students, and Florence Fox, ca. 1921

Source: By permission of Wider Church Ministries, United Church of Christ and Houghton Library, Harvard University (ABC78, box 15, folder "Fox, Florence").

This photograph is emblematic of the colonial archive, an embodiment of the limits and possibilities of research therein. Its elements recur throughout archival documents, as well as early twentieth-century publications. Imperial power required an ideological erasure of indigenous peoples; they mattered in the aggregate, but did not figure as individual human beings. ${ }^{3}$ Colonial records are part of the "spoils of rule," as scholar Antoinette Burton eloquently puts it, wherein women's experience is fragmented, and indigenous women's voices prove most elusive of all. ${ }^{4}$

\footnotetext{
3 This study draws from extensive archival research in the collections of the American Board of Commissioners to Foreign Missions, Houghton Library, Harvard University (hereafter abbreviated as ABC), as well as in a broader range of published primary sources, especially those of women's foreign mission societies, such as Life and Light for Woman and Woman's Work for Woman.

4 Antoinette Burton, "Archive stories: gender in the making of imperial and colonial histories," in Gender and Empire, ed. Philippa Levine, NY: Oxford University Press, 2004, pp. 281-93. As Jeffrey Cox notes in frustration, "The missions recruited large numbers of women assistants of various kinds, classified under shifting categories in the statistical tables and often identified individually not by name [my emphasis] but as a 'bible woman."” Jeffrey Cox, Imperial Fault Lines: Christianity and Colonial Power in India, 1818-1940, Stanford, California: Stanford University Press, 2002, p. 104. On the importance of visual representations, especially photographic images, to the United States' imperial power in the Philippines, see David Brody, Visualizing American Empire: Orientalism and Imperialism in the Philippines, Chicago: University of Chicago
} 
The visual image meanwhile persists. Its caption may not fill in the photograph's silences, but the photograph remains undiminished. It may be challenging to "read" but it should count as more than just ephemera or illustration. ${ }^{5}$ Although anonymous, the Filipinas are compositionally and actually central to the scene. They provide the reason for the photo, the reason for the American missionary women's presence in their country in the first place. They are the subjects (in both senses of that maddeningly ambiguous word): subjected to missionisation, to imperialism, to our gaze; but also comprising the Subject, the topic and focus of the camera. The visual medium reveals their individual humanity, as perhaps only a photograph can; pictorially, these four Filipina women are no less individual nor human than their white American counterparts. The photograph also documents relationships among women, across nationality and race. The Americans enclose the Filipinas, but their bodies all turn in the same direction, forming a row. The Filipinas display different forms of adaptation to American fashion and culture, including a style of womanhood of their own.

Despite the near invisibility of Filipinas in the archival record, one may find traces of these women's significance to the missionary enterprise, of their agency and action, of the effect they had on American women, and of the influences and pressures that they felt in turn. A "ubiquitous anonymity" frames the experience of the Filipinas who visited or lived at the mission, sought education or medical care there, forged personal connections to the Americans, perhaps converted to Protestant Christianity, and sometimes became evangelists themselves. Though infrequently named or given a place to address United States audiences through missionary publications or official correspondences, Filipinas' significance to the mission enterprise means the surviving sources nevertheless register their presence.

To private correspondents and sometimes to public audiences as well, photographs attested to the importance and success of foreign missions. Letters and reports by Isabel Fox help identify the women who likely posed for this promotional image, though in sending the photograph to Woman's Board secretary Kate Lamson, Fox referred to them only collectively as "the group of Bible Students." ${ }^{\prime 6}$ Elisea Eguia, Nicomedesa Miranda and Isabel Maandig had attended the Cagayan Women's Bible Training School since it began in 1919. There they learned about sanitation and "a true home ideal" as well as about theology, church history and sacred music. They served as models of Christian comportment to dormitory residents (who attended the regional public high

\footnotetext{
Press, 2010; Benito M. Vergara Jr., Displaying Filipinos: Photography and Colonialism in Early 20th Century Philippines, Quezon City: University of the Philippines Press, 1995; Laura Wexler, Tender Violence: Domestic Visions in an Age of U.S. Imperialism, Chapel Hill: University of North Carolina Press, 2000.

5 Hyaeweol Choi, "The visual embodiment of women in the Korea mission field," Korean Studies 34 (2010): 90-126, evocatively analyses depictions of women in missionary photography.

6 Anna Isabel Fox to Kate Lamson, 30 April 1922, Mrs. Isabel Fox Smith letters, ABC 17.9.2.
} 
school) and to visiting girls' athletic teams. Eguia had accompanied Fox on a trip to promote the mission dormitory, journeying to remote villages where Fox declared herself to be "the first American woman to visit." ${ }^{\prime 7}$ As a senior, Maandig taught Christian doctrine in the school and became an assistant matron. She and her peers then fanned out to teach over a span of 500 kilometres (310 miles) along the coast of northern Mindanao. ${ }^{8}$ The fourth Filipina may be Miss Chacon, the station's secretary and native assistant.

Considered in context, this photograph reveals the complex ways in which American missionaries helped to shape Filipinas' ideas about modern womanhood. Scholars have begun to recognise that mission stations were important sites of exchange, spaces where Americans attempted to evangelise their culture, nation and gender ideology along with their version of the Gospel, yet found that they had to adapt to local circumstances to some degree. ${ }^{9}$ This essay considers Bible women and dormitory residents, their pursuit of more public roles and the politics of dress in particular, and addresses the extent to which the Filipinas exercised agency within Protestant missions. Seen from the Filipina women's perspective, the chance to become Bible women represented a desirable change, especially compared to the subservience dictated for women during the Spanish colonial period. A broader spectrum of Filipinas used missions to gain greater access to education. While they seemingly embraced contemporary American definitions of gender, their concerns about feminine respectability influenced the development of girls' dormitories. And while Filipinas adopted American-style aspirations to participate in athletics and the professions, they also looked to particular arenas, such as dress and bodily practices, to remain culturally distinct from American women. Filipinas at the mission thus developed and enacted their own version of modern womanhood, with a range of meanings and results.

7 Anna Isabel Fox to friends, 31 March 1922, Mrs. Isabel Fox Smith letters, ABC 17.9.2.

8 Woman's Board of Missions, Philippines, 1915-1927, Documents and Reports, ABC 17.9.2.

9 Studies of the U.S. occupation of the Philippines focus nearly exclusively on the military and the federal government as imperialist agents of "benevolent assimilation." Kenton Clymer, Protestant Missionaries in the Philippines, Urbana: University of Illinois Press, 1986 and Susan K. Harris, God's Arbiters: Americans and the Philippines, 1898-1902, NY: Oxford University Press, 2011 are among the rare exceptions. Studies of the other colonial possessions that the United States won from Spain in 1898 similarly consider missionaries separate from federal interventions - if they consider missionaries at all. (Hawai'i followed a different model, perhaps because missionaries and merchants preceded annexation.) This overlooks how government and missionary enterprises worked in tandem, toward shared goals of Christianity and civilisation. Indeed, Christianity and civilisation are impossible to disaggregate from one another in America's imperialist rhetoric (and sometimes its policies). See Barbara Reeves Ellington, Kathryn Kish Sklar and Connie Shemo (eds), Competing Kingdoms: Women, Mission, Nation, and the American Protestant Empire, 1812-1960, Durham, NC: Duke University Press, 2010. 


\section{Gender and mission under occupation}

American Protestant evangelism embarked for the Philippines after 1898, when the United States took possession of the archipelago. ${ }^{10}$ The missionary enterprise thus accompanied and largely reinforced United States rule in the Philippines. Unlike in other places (such as China) where missionaries were reluctant to foment social change, ${ }^{11}$ missionaries were in the Philippines for the purpose of change. The colonial context called upon them to help modernise and Americanise as well as "Christianise" the Filipino people. ${ }^{12}$ As President William McKinley proclaimed in 1898, the United States saw its mission in the Philippines not as the rapacious colonisation of "invaders or conquerors," but a "benevolent assimilation," whereby the United States would inculcate native peoples in the "individual rights and liberties which [are] the heritage of free peoples." While the United States refused to recognise Filipino independence in 1898, it simultaneously denied the intent to govern the Philippines "permanently as colonies."13 American women's presence was crucial to conceptualising and representing United States' imperialism and assimilation as "benevolent" in this manner. Like teachers, nurses and wives, women missionaries enacted a maternalist imperialism, pioneered in the American West, that tempered impressions of aggressive, rapacious territorial expansion. ${ }^{14}$

The planting of United States' imperialism, and of American Protestant missions, in the Philippines coincided with a particular historical moment when gender ideals were under transformation on both sides of the Pacific. The ideology of domesticity had been central to "woman's work for woman" in missionary work throughout the nineteenth century; American women around the world celebrated the exaltation of motherhood, homemaking and nurture that in their eyes Christianity conferred. ${ }^{15}$ But American women's participation in the public sphere had radically expanded since that earlier celebration of female domesticity. The New Woman was vivacious, physically active and confident in her own abilities. Heterosociality and other aspects of modern American culture

10 See Clymer, Protestant Missionaries in the Philippines.

11 See Leslie H. Flemming, "Introduction," in Women's Work for Women: Missionaries and Social Change in Asia, ed. Flemming, Boulder, San Francisco, and London: Westview Press, 1989, pp. 1-10.

12 I use quotation marks for "Christianise" because the majority of Filipinos were Catholic, thus already "Christian" at the time.

13 Paul A. Kramer, The Blood of Government: Race, Empire, the United States, and the Philippines, Chapel Hill: University of North Carolina Press, 2006, pp. 109-10.

14 Peggy Pascoe, Relations of Rescue, NY: Oxford University Press, 1990; Amy Kaplan, “Manifest domesticity," American Literature 70(3) (September 1998): 581-606.

15 Jane Hunter, "The home and the world: the missionary message of U.S. domesticity," in Women's Work for Women: Missionaries and Social Change in Asia, ed. Leslie A. Flemming, Boulder, San Francisco and London: Westview Press, 1989, pp. 159-66, p. 159. 
began to challenge the gender-separate women's missionary movement. ${ }^{16}$ The increasing numbers of single women missionaries were themselves ambivalently domestic at best. Like other young women of their generation, they embraced new ideals of public engagement, advanced education, professionalism, wage earning and physical vigour. An advertisement for a teacher of religious education and music in the Philippines required not only "thorough knowledge of the Bible [and] special training in Sunday School work" but "a strong constitution," "a college education," and "executive ability." The Woman's Board flyer touted the "social life" available as an attraction of the position"splendid opportunities for tennis, rides by automobile and horse, walks along splendid roads and by the sea, sea-bathing and boating, etc." ${ }^{17}$ Along with the "wonderful opportunity to win the women of the Island, civilized, pagan, and Mohammadan, to Christ," missionary women could apparently expect to enjoy themselves in athletic recreation. ${ }^{18}$ They would hold positions of authority, earn wages and practise their professions.

It was this revised vision of femininity, rather than strict piety and domesticity, which American missionary women carried to the Philippines in the early twentieth century. "Modern womanhood" was itself offered as evidence of Americans' cultural superiority to "orientals" whose men sequester and dominate their women. According to the scientific racism still prevalent in the 1910s and 1920s, "primitive" societies oppressed women. "Savage" women were drudges who did all the heavy work (of agriculture, for instance) while their men lounged; or they were cloistered, denied any social role apart from motherhood, and hampered even in that by their enforced ignorance. As implicitly taught by the missionaries, "modern womanhood" encompassed by contrast a thorough education, including literature, social science and science. It fitted women to contribute to society more broadly as teachers or nurses, as well as to become better-informed mothers. It encouraged robust health through physical activity and the care of medical experts. It embraced consumer culture as an expression of American-ness.

Multiple historical developments shaped conceptions of gender in the Philippines in the same period. With its Malay origins, Islamic influence in the South, and centuries of Spanish colonisation, the Philippines' complex culture not only differed from the United States but from other parts of Asia. As the young Filipina ethnologist Ramona S. Tirona explained in 1920, "a sort of common law, based upon [Malayan] custom and tradition," long ago accorded Filipinas greater rights

\footnotetext{
16 Another important change in the 1920s was the ecumenical emphasis on "World friendship" and social justice, as well as the encouragement of indigenous leadership. This last proved deeply compatible with the U.S. federal policy of "Filipinisation" of civil service on the islands.

17 “WANTED: Teacher of Religious Education and Music. Cagayan, Mindanao, Philippine Islands," folder 1:9 Special Papers: C, Box 1, ABC9.5.1.

18 Ibid.
} 
and privileges than American or English women had. ${ }^{19}$ Filipino men recognised women as social equals, even though women could not vote. Filipinas took responsibility in fiscal matters and owned property. Their authority was not only as mothers within their families, but over their tribes. ${ }^{20}$ American missionaries noted too how women served as "the managers of the home," and that the female sex was held in "high regard and respect ... far above the social status of women in all other Oriental cultures." ${ }^{21}$ Diverse native customs and religions persisted albeit to different degrees in the various provinces.

At the same time, Spain had left a strong legacy of patriarchy after three-hundred years of colonial rule in the Philippines. The coloniser's culture particularly influenced the Filipino élite, whose sons were educated in the Spanish language and according to the Spanish system (and sometimes in Spain itself). Thus, the pious, virtuous feminine type exalted by Filipino nationalists in the late nineteenth century had more qualities in common with contemporary Spanish ideals of womanhood than with the babaylan (animist priestesses) who had wielded power in precolonial Filipino communities. ${ }^{22}$ Despite a legal tradition according property and inheritance rights to women, Spanish ideology defined women socially and politically by their relation to their husbands and fathers. Anxiety over miscegenation from the mingling of Christians, Jews and Muslims in Spain had bequeathed a deep concern over "pure" bloodlines and a social imperative to control women's sexuality. ${ }^{23}$ A family's honour was considered to rest upon the virtue of its female members. Catholicism - so prominent in Spain, and the basis of what public schooling existed in the Philippines before 1898 - emphasised modesty, domesticity and a pure motherhood, in emulation of Jesus' mother, the Virgin Mary.

Modernity revised notions of womanhood around the world in the early twentieth century, but took on a particular caste in the Philippine Islands due to the contemporary context of anti-imperialism, revolution and war. Though the wars for independence had called women to fill unfamiliar roles, even on the battlefield, Filipino nationalists saw politics and public life in masculine terms.

\footnotetext{
19 Ramona S. Tirona, "The Filipino woman: what she is and what she is not," Philippine Herald 1(2) (Dec 1920): 3-7. Tirona (1888-1947) wrote several ethnological studies of Tagalog customs and beliefs, now collected at the National Library of the Philippines. She studied in the United States and later at the University of London.

20 Tirona, "The Filipino woman."

21 Charles Briggs, The Progressing Philippines, Philadelphia: The Griffith and Rowland Press, 1913, p. 150.

22 Barbara Watson Andaya, "Gender, warfare, and patriotism in Southeast Asia and the Philippine revolution," in The Philippine Revolution of 1896: Ordinary Lives in Extraordinary Times, ed. Florentino Rodao and Felice Noelle Rodriguez, Quezon City: Ateneo de Manila University Press, 2001, pp. 1-30, pp. 6, 8-9; Patricio N. Abinales and Donna J. Amoroso, State and Society in the Philippines, NY: Rowman \& Littlefield Publishers, Inc., 2005, pp. 58-59.

23 Theresa Ann Smith, The Emerging Female Citizen: Gender and Enlightenment in Spain, Berkeley: University of California Press, 2006, p. 23.
} 
They did not write of women as potential citizens but rather as "symbolic mothers" and the keepers of tradition. ${ }^{24}$ The popular icon of beautiful María Clara (from José Rizal's novel, Noli Me Tángere) exemplified the ideal place of women in the nation, at least in the eyes of its male architects. ${ }^{25}$ These ideas remained strong after the unsuccessful attempt to overthrow the United States' colonial power there; pockets of armed resistance continued decades after the official end of the "Philippines Insurrection" in 1902.

As they worked alongside the federal goal of civilising and "Christianising" the Philippines, United States missions interlaced conventions of domesticity and separate spheres with more "modern" ideas about womanhood. Missionaries attempted to encourage both Filipina women's domestic interests and their more modern ambitions. American domesticity resounded with the Spanish Catholic colonial legacy and with the Filipino nationalist ideal of femininity that sprang up from it. It was not the True Woman but the New Woman who corresponded to the urban development, educational system, progressive and professional ethos by which United States "benevolent assimilation" purported to "modernise" its colonial acquisition from Spain. Ideals of progress and modernity became inextricable from American culture. Being a modern Filipina in the 1910s and 1920s, explains historian Mina Roces, "meant speaking English, getting an education, and taking up new roles in the public sphere." ${ }^{26}$ As a consequence, wrote Ramona Tirona, "the representative Filipino woman of today is a curious combination of three influences - the Malayan, the Spanish, and the American." ${ }^{27}$ Within the crucible of empire, it rested with Filipinas to determine what sort of womanhood best suited their aspirations, their ideals and their pragmatic concerns.

\footnotetext{
24 On gender and Filipino nationalism, see Vicente Rafael, White Love and Other Events in Filipino History, Durham, NC: Duke University Press, 2000 and The Promise of the Foreign: Nationalism and the Technics of Translation in the Spanish Philippines, Durham, NC: Duke University Press, 2005; Raquel A.G. Reyes, Love, Passion, and Patriotism: Sexuality and the Philippine Propaganda Movement, 1882-1892, Singapore: National University of Singapore Press, 2008.

25 José Rizal, Noli Me Tángere, Valencia, Spain: F. Sempere, 1887. For a comparative view, see Suruchi Thapar-Bjorkert and Louise Ryan, "'Mother India/Mother Ireland' comparative gendered dialogues of colonialism and nationalism in the early 20th century," Women's Studies International Forum 25(3) (May-June 2002): 301-13.

26 In the eyes of Spanish-identified critics, this sort of woman was a sajonista or "Saxonist." Mina Roces, "Women in Philippine politics and society," in Mixed Blessing: The Impact of the American Colonial Experience on Politics and Society in the Philippines, ed. Hazel M. McFerson, Westport CT: Greenwood Press, 2002, pp. 159-89, pp. 161, 181.

27 Tirona, “The Filipino woman," pp. 3-7.
} 


\section{Bible women}

Filipina women's ideas of modern womanhood aligned most closely with those of American missionary women in the role of Bible women. Strongly nineteenthcentury cultural assumptions about "sisterhood" dictated that women made the best emissaries to other women, across lines of race, class, language and nationality. Foreign mission board officials, fundraisers and missionaries in the field all concurred that they needed not only American but also native women workers to spread the gospel in the Philippines, as they had elsewhere. Thus, trained native women evangelists, known as "Bible women," had been part of the Woman's Board's missiological vision since its inception in 1869. Bible women throughout foreign missions performed similar and vital tasks: the work of visiting, distributing Christian literature, teaching Bible and Sunday school classes, leading prayer and sometimes providing medical care. ${ }^{28}$ They engaged in pastoral work in partnership with Euro-American women missionaries as well. ${ }^{29}$ Indigenous women's evangelical work was considered so important that American women's missionary societies supported almost triple the number of native Bible women as they did American women in the field. ${ }^{30}$ This reliance only increased with time. ${ }^{31}$

Bible women quickly became indispensable to American Protestant missionaries in the Philippines. ${ }^{32}$ Filipina women reportedly exerted formidable influence over their husbands and children, and thus would make exceptionally valuable Bible women. Frederick Jansen of the Presbyterian mission in Cebu carefully noted that, "We need to reach the women of the islands very specially in order to make the work count most." ${ }^{33}$ Furthermore, their indigenous culture

28 A burgeoning body of scholarship addresses Bible women. See Hyaeweol Choi, Gender and Mission Encounters in Korea: New Women, Old Ways, Berkeley: University of California Press, 2009; Mrinalini Sebastian, "Reading archives from a postcolonial feminist perspective: 'Native' Bible women and the missionary ideal," Journal of Feminist Studies and Religion 19(1) (2003): 5-25; and "Transnational Biblewomen: Asian and African women in Christian mission," special issue of Women's History Review 17(4) (September 2008): 489-500. Several of the earliest studies incorporating Bible women appear in Leslie A. Flemming (ed.), Women's Work for Women: Missionaries and Social Change in Asia, Boulder, New York and London: Westview Press, 1989.

29 According to the initial organisation of "native female helpers" by the Woman's Board from 1869, "Each Bible-woman is under the superintendence of a female missionary, whose aim is to make this largely a work of love." Mrs. Miron Winslow, "Our Bible-Women," in Third Annual Report, Woman's Board of Missions, Boston: Rand, Aver and Frye, 1871, ABC 91.6.

30 Dana L. Robert, "Protestant women missionaries: foreign and home," in Encyclopedia of Women and Religion in North America, vol. 1, ed. Rosemary Skinner Keller, Rosemary Radford Ruether and Marie Cantlon, Bloomington: Indiana University Press, 2006, pp. 834-43, p. 837.

31 Helen Barrett Montgomery, Western Women in Eastern Lands: An Outline Study of Fifty Years of Woman's Work in Foreign Missions, New York: the Macmillan Co., 1911, p. 117.

32 "Field Correspondents / Miss Anna Isabel Fox of Cagayan, Philippine Islands, writes," Light and Life for Woman 52(5) (May 1922): 197.

33 Jansen to Arthur Brown, 10 Dec 1910, quoted in Kenton Clymer, Protestant Missionaries in the Philippines, 1898-1916, Urbana and Chicago: University of Illinois Press, 1986, p. 81; also see Frank Laubach to Kate Lamson, 28 January 1921, ABC 17.9.2. Missionaries made similar arguments about indigenous women's 
made the mission work relatively easy for Filipinas to take on, especially in comparison with other Asian women. "Girls and women of the Islands have an unquestioned freedom and independence of action in daily business and social life," unlike the "seclusion of the zenana," commented Presbyterian missionary Anna Rodgers Wright. ${ }^{34}$ Baptist missionary Charles Briggs agreed, "Single women can do effective work in the Philippines [because] there is little of the social prejudice against their sex, or of false ideas about womanhood that will hinder [them]." Even if "there is some prejudice against their preaching in public, yet some of them have even done this effectively." 35

Although donors and bureaucrats might insufficiently appreciate them, Bible women's achievements were apparent to the missionaries in the field. "Without them the work could not have been carried on," wrote Woman's Board missionary Isabel Fox, pressing for increased salaries to sustain the Bible women. ${ }^{36}$ Unlike missionaries, native women "go into the homes, and meet the people on a common ground," Fox commented candidly. Bible women did not merely translate American missionaries' messages; they put their own perceptions and skills to use in the field. As a result, even after Fox gained fluency in Visayan, she continued to tour with "our woman evangelist" (perhaps Elisea Eguia). In 1922, for example, the pair went on a long and successful trip to recruit dormitory and Bible School students. ${ }^{37}$

Religious faith was certainly the most powerful factor motivating Filipinas to become Bible women. Many felt their vocation strongly; one woman chose to become a Bible woman rather than continue pursuing medicine. They learned about inspirational figures like Isabella Thoburn and Pandita Ramabai from missionaries. ${ }^{38}$ Yet the position of a Bible woman could afford other sorts of fulfilment and opportunity beyond the spiritual call. Bible studies meant an opportunity for literacy and education as well as mobility. Education in turn helped Filipinas find employment. In fact, public schools could be competition for employment. Isabel Fox returned from a tour to find all five of the girls she had lined up for evangelical work "scattered" to teaching positions elsewhere. ${ }^{39}$ Filipinas themselves possibly regarded these teaching posts as interchangeable.

influence over their families in other contexts as well. See, for example, Carol Devens, "'If we get the girls we get the race': missionary education of Native American girls," in The Girls' History and Culture Reader, ed. Miriam Forman-Brunell, Urbana: University of Illinois Press, 2011, pp. 104-19.

34 (Mrs George W.) Anna Rodgers Wright, "What Christian women are doing in the Philippines," part I, Woman's Work (June 1918): 133-34, p. 133.

35 Briggs, The Progressing Philippines, p. 150.

36 [Isabel and Evelyn Fox], “The Cagayan Women's Bible Training School,” ca. 1924, ABC 17.9.2.

37 AIF to friends, 31 March 1922, ABC 17.9.2; letter published as "Touring in tropical seas by Anna Isabel Fox," Life and Light for Woman LII(10) (October 1922): 365.

38 (Mrs. J.L.) Rosalie Hooper, “Our young women's conference," Woman's Work 35(6) (June 1920): 125-26, p. 126.

39 Anna Isabel Fox to Kate Lamson, 7 June 1920, ABC 17.9.2. 
Others relished the opportunities for leadership and even sociability that Bible training entailed. For example, a Girls' Bible Conference began convening at Baguio in 1918. The ecumenical conference offered Filipinas a chance to represent their country in an international gathering. In 1920, sixty-one young Filipinas joined representatives from multiple countries (China, Siam and the United States) and denominations (Methodist, Presbyterian and United Brethren). Attendees also evinced "a genuine girls' love of the social" at the mountain resort of Baguio. Part of the thrill was being "the first girls that ever had a chartered coach in the Philippines," according to Rosalie Hooper. ${ }^{40}$

The mission could bring together young women with men from outside of their usual circles, men who would not conventionally gain family approval. But Bible women could count on missionaries' support and even intervention if they defied traditional ideas about marriage, to select companions out of romantic love or in service to their new faith. For example, "Miss Iligan," the matron of the Ellinwood Bible School and Dormitory in Manila, at first incurred "her father's displeasure" when she accepted the marriage proposal of "one of the young preachers" at the mission; but "relatives and neighbors" overcame his opposition, and the young woman was able to marry a husband of her choosing. ${ }^{41}$ Another Ellinwood graduate, Maria Vidallon, likewise turned to the "judicious help" of her "missionary friends" when she decided to wed Matias Cuadra. Her family had multiple reasons to object: Vidallon was Tagalog, while Cuadra was Moro, and the marriage would uproot her from her community to become a preacher's wife in the South. Yet, missionary Charles Gunn proudly reported, "after a long discussion following the graduation exercises, the match was agreed to by the parents in true grudging Filipino fashion." ${ }^{42}$ The first Filipino Muslim to convert to Protestantism, Cuadra became the first Moro minister, and Maria served alongside him as a home missionary. ${ }^{43}$

Marriage to a fellow convert shows how Filipina Bible women (like American women) tried to integrate domesticity with missionary work. Anna Rodgers Wright proudly noted how Emilia Saprid, one of the "bright girls from the provincial towns, who show capacity for leadership," graduated from the mission's school one day and married Domingo Cavan, "one of our strong Christian boys," the next. Emilia Saprid might "continue to help for another year," teaching music and Bible at her alma mater; after that, she would exert

\footnotetext{
40 For the later history of this conference, see subsequent articles in Woman's Work.

41 Presbyterian Church in the U.S.A., Board of Foreign Missions, Annual Report 84 (1921): 351.

42 Charles A. Gunn, “Romance and education go hand-in-hand," Woman's Work 35(6) (June 1920): 130-31, p. 131. Such stories provided subtle evidence of missionaries' effectiveness in introducing more American ideals of marriage as well as rational discourse versus savage customs and superstition.

43 Frank Laubach, Thirty Years with the Silent Billion, London: Lutterworth Press, 1932, pp. 45-62. Also see Matias Cuadra, The Problem of Presenting the Life of Jesus to the Moro Students of the Philippines, New York: Union Theological Seminary, 1930; and Laubach, Seven Thousand Emeralds, New York: Friendship Press, 1929.
} 
Christian influence only within the stricter compass of her home and family. ${ }^{44}$ Missionaries were also ready to support Filipinas who forewent marriage entirely, however. Missionary wives certainly meant to serve as models but their families competed for their time and energy - indeed, the main example that missionary wives set was how to keep a Christian home and nurture children. Visiting and teaching beyond the confines of the mission station "can be done only by a woman not tied down to the home or classroom," Wright admitted..$^{45}$ In fact, tensions erupted in the 1920s over whether missions "should" be training women to be pastors' wives or to be Bible scholars.

Whether married or single, Bible women took on important work as teachers, evangelists, deaconesses and religious leaders. Beginning during their training, Filipinas taught Sunday schools, some leading multiple classes. Often the American women would initiate a woman's class and then hand it over to the "older girls." For example, Miss Chacón, the first Bible woman in Mindanao, worked first as Frank Laubach's secretary, then as Isabel's "companion and assistant," and led evening prayers at the girls' dormitory. Isabel Maandig began teaching Christian doctrine at the Carruth Bible School even before she graduated in 1924. The Woman's Board then employed Maandig through 1927, regularly raising her annual salary during that time. She went on to organise her own Visayan Woman's Bible Class and the majority of her students became members of the church. ${ }^{46}$

Bible women also travelled to other towns to evangelise, organise classes and women's meetings, and recruit dormitory residents. ${ }^{47}$ In Dipolog, Elisea Eguia organised and taught her own kindergarten, while her classmate Nicomedesa Miranda worked in Cabadbaran. The young Bible students at Jaro covered a large area on foot ("and barefoot at that"), having begun "two Bible classes for children, one in each town," and baptising converts themselves. "We have a prayer meeting here three times a week. We go from house to house among the members and we all pray, every one of us. Then too, we go into the Catholic part." They approached people both in their homes and in public markets, singing hymns to attract attention. ${ }^{48}$ It was a small step from these initiatives to extended service on their own, without the companionship or supervision of a United States missionary. The Baptist Bible women in Iloilo, for instance, continued their work independently for a year and a half after the American

44 (Mrs. George W.) Anna Rodgers Wright, "What Christian women are doing in the Philippines," part II, Woman's Work (July 1918): 157-58, p. 158.

45 Ibid.

46 G. Evelyn Fox, “Fourth Annual Report of the Woman's Bible Training School," 1923, ABC 17.9.2.

47 See Anna Isabel Fox to Kate Lamson, 19 October 1922, ABC 17.9.2.

48 Anna V. Johnson, “In training at Jaro," Helping Hand (1909): 15. 
woman missionary there fell gravely ill. ${ }^{49}$ A Bible woman shepherded the "substantial congregation" at Buenavista, which was without a regular pastor. ${ }^{50}$ Soon the missions were receiving requests for regular Filipina deaconesses (Pastoras) from Filipino churches. ${ }^{51}$

Not every mission granted Bible women such responsibilities and autonomy. Jaro closed its Training School during founder Anna Johnson's furlough rather than leave it in the hands of a Filipina woman alumnae. But a number of Filipinas gained positions of authority as teachers and preachers in their own right. The periodical Woman's Work reported on the electric effect of a Bible woman named Catalina. "In one of the Iloilo villages, Catalina has been instrumental in bringing many to the Saviour, she being the maestra or village teacher and a woman of great influence. Recognising the advantage of such influence, a class has been instituted for women and in every village as far as convenient some bright young woman has been selected to receive special instruction." 52

Women evangelists such as Josefa Abierta and Julia Sotto de Yapsutco epitomised the modern, Christian Filipina on these lines. Abierta's death in 1922 cut short a brilliant beginning as a lawyer and founder of the Philippine Chapter of the Women's Christian Temperance Union. She had been one of the first Baptist converts in Capiz. ${ }^{53}$ Yapsutco was also well educated, started a women's club and worked ardently in her faith. She inspired her husband's conversion, published a religious periodical, taught the Bible, and became a preacher after her husband's death. Yapsutco eventually became a pastor of the United Evangelical Church of the Philippines in Iligan, Lanao, with a congregation of about a hundred, both American and Filipino. ${ }^{54}$ She became, like the Woman's Board of Mission workers, a woman with other women's concerns at heart, but not limited to the domestic circle. She used her position as Bible woman assertively, demanding that the United States live up to the promises of benevolent assimilation. "Give us institutions and dormitories so as to produce people for Christ. While we cannot have this, you cannot expect the Filipino Christians to take care of the pagans in the Philippines," Yapsutco exhorted in a letter to missionary Frank Laubach. ${ }^{55}$ Clearly, in Yapsutco's vision, the United States should provide the means, but Filipinos would do the work of Christ themselves.

\footnotetext{
49 Perla D. Belo, "Anna V. Johnson: missionary pioneer, educator, and evangelist," American Baptist Quarterly 12 (1993): 283-96, p. 286.

50 “Field Work September 15 to October 27, East Coast," typescript manuscript, Folder 65:19, ABC 77.1.

51 Clyde Bartholomew, "The new generation in the Philippines," Woman's Work (June 1919): 125; Presbyterian Church in the U.S.A., Annual Report 85 (1922): 384.

52 “Report of Philippines Mission," Woman's Work 20 (1905): 154.

53 American Baptist Historical Society, The Chronicle (1938): 172.

54 Photograph, “Iligan, P.I. Pastor - Mrs. Julia Yapsutco," folder 20.8, box 20, ABC 78.2.

55 Letter to Frank Laubach; published as Julia de Yapsutoo [sic], "Field Correspondents," Light and Life for Woman 51(6) (June 1921): 234.
} 
As with their male counterparts, education and authority led Bible women not simply to assimilation, but to the means of expressing resistance to prolonged rule by the American missionaries who acknowledged the unusual strength of independence movements. ${ }^{56}$ Isabel Fox Smith came to advocate "cooperation" with Filipinos in the face of their "very strong nationalistic feeling." 57 Missionaries would need to be partners, not directors, in order to instill loyalty in local populations. The prominence of native evangelists, including Bible women, mirrored the gradual "Filipinisation" of civil service, by which the United States federal government planned a gradual transition to self-government. Yet nineteenth-century Filipino nationalism had had a strong anti-clerical inclination. Just as Catholic friars had seemed the arm of Spain's colonial power, so did some view missionaries as the embodiment of American imperialism. Indeed, prominent American Catholics lobbied hard to prevent the independence of the Philippines. ${ }^{58}$ At its extreme, nationalism demanded separate, indigenous Christian churches. ${ }^{59}$ More commonly, Bible women, male preachers, and congregations remained part of American church structures while resisting linguistic and cultural assimilation. For example, Ang Dalan, the weekly religious paper that Julia Sotto de Yapsutco edited, was in Visayan, not English, and she spent many years helping to translate the Bible into Visayan. ${ }^{60}$ Bible women saw their task as that of converting their people to Protestantism, not to Americanism.

\section{A modern education}

Becoming a Bible woman involved more than just vocation; education was the key to transforming Filipinas into beacons of Christianity. American and Filipina women both embraced education enthusiastically as a highly desirable facet of modern womanhood. Equally innovative women's education, at Mount

\footnotetext{
56 Anna Isabel Fox, "Summer work at Cagayan," Light and Life for Woman 52(9) (Sept. 1922): 322-24, p. 323.

57 Isabel (Fox) Smith to Mabel Emerson, 25 May 1926, ABC FM 17.9.2.

58 Kramer, The Blood of Government, pp. 358-60.

59 In 1909, Methodist Episcopal convert Nicolas Zamora had broken with American churches to found $\mathrm{La}$ Iglesia Evangelica Metodista en las Islas Filipinas (IEMELIF) and thereby bringing "Christ to the nation the Filipino way." See F. Albert Tizon, "Filipino Protestant faith in revolutionary times: historical elements in an evangelical theology of social transformation," Journal of Asian Missions 4(1) (2002): 3-30, p. 9.

60 Frank J. Woodward to Luella E. Jones, 9 April 1942, Box 80 folder 66:7 - Yapsutco, ABC 77.1.
} 
Holyoke for example, had transformed American Protestant women into foreign missionaries. ${ }^{61}$ In turn, the United States' women's missionary movement had founded over 3,200 schools around the world by $1909 .{ }^{62}$

The novel prospect of education appealed to many Filipinas, not only those who sought preparation as Bible women, but also those who had yearned for secular schools and advanced study. In fact, some of the women who travelled to Iloilo to attend the new Women's Bible Training School decided the public school suited them better. The Spanish had not proscribed education for women; provincial parochial schools taught both boys and girls. But even after some reform and expansion starting in the mid-nineteenth century, the under-funded colonial education system reached only very small numbers of Filipino children (200,000 elementary students at its peak in 1898). De jure compulsory education did not reach the general population de facto. As a result, in 1900, only 30 per cent of men and 10 per cent of women in the Philippines were literate. ${ }^{63}$

Missions in the Philippines did not need to build their own system of schooling in reading and other basics, as they did elsewhere, because of the active attention that the United States gave to expanding education upon taking possession of the archipelago. This education was a cornerstone of "benevolent" imperialism, ${ }^{64}$ that is, as a tool to "uplift, Christianize, and civilize" the Filipino, eventually paving the way for Filipino self-government. The federal commissioner of education proudly reported that "throughout the archipelago, the schoolhouse follows the flag." 65 He could as well have said that the schoolhouse followed

61 On various aspects of education and women missionaries, see Amanda Porterfield, Mary Lyon and the Mount Holyoke Missionaries, New York: Oxford University Press, 1997; Patricia Hill, The World their Household: The American Woman's Foreign Mission Movement and Cultural Transformation, 1870-1920, Ann Arbor: University of Michigan Press, 1985; Jane Hunter, Gospel of Gentility: American Women Missionaries in Turn-of-the-Century China, New Haven: Yale University Press, 1984; Margaret Jolly and Martha Macintyre (eds), Family and Gender in the Pacific: Domestic Contradictions and the Colonial Impact, Cambridge: Cambridge University Press, 1989; Gael Graham, Gender, Culture and Christianity: American Protestant Mission Schools in China, 1880-1930, New York: Peter Lang Publishing, 1995; Mary Taylor Huber and Nancy C. Lutkehaus (eds), Gendered Missions. Women and Men in Missionary Discourse, Ann Arbor: University of Michigan Press, 1999; Dana Robert, Gospel Bearers, Gender Barriers: Missionary Women in the $20^{\text {th }}$ century, Maryknoll NY: Orbis Books, 2002; Dana Robert, American Women in Mission, Macon GA: Mercer University Press, 1996; Maina Chawla Singh, Gender, Religion and "Heathen Lands": American Missionary Women in South Asia, 1860s-1940s, NY: Routledge, 1999; Ruth Tucker, Guardians of the Great Commission, Grand Rapids MI: Academie Books, 1988; C. Insun Yoon, “Civilizing mission for women,” Ph.D. diss., Madison NJ.: Drew University, 2008.

62 Robert, "Protestant women missionaries: foreign and home," p. 837.

63 Carolyn Israel Sobritchea, "American colonial education and its impact on the status of Filipino women," in Women's Role in Philippine History: Selected Essays, University Center for Women's Studies, Diliman, Quezon City: University of the Philippines, 2001, pp. 79-108, p. 81.

64 Benjamin Justice, "Education at the end of a gun: the origins of American imperial education in the Philippines," in American Post-Conflict Educational Reform: From the Spanish-American War to Iraq, ed. Noah W. Sobe, New York: Palgrave Macmillan, 2009, pp. 19-52, p. 35. Also see Stuart Creighton Miller, Benevolent Assimilation: The American Conquest of the Philippines, 1899-1903, New Haven CT: Yale University Press, 1984. 65 F.F. Hilder, "Education in the Philippines," Annual Reports of the Department of the Interior, Report of the Commissioner of Education, 1898-1899, LX; quoted in Justice, "Education at the end of a gun," p. 40. 
the Army, since the United States military established schools in the wake of pacification-"poor," "aimless" and "chaotic" as the American Philippine Commission reported those schools were ${ }^{66}$ Act No. 74, the Organic School Law of the Philippines (1901), formed "a formal, civilian Bureau of Education" and established ten permanent school divisions throughout the islands. The United States' system of public education encompassed primary schools, intermediate industrial schools focusing on practical education, and one high school per province. The federal government built over 4,000 public schools by 1910, serving 355,722 elementary school students and 3,400 high school students: more than double the number under Spanish rule. Enrolment reached almost a million by 1920, though even this did not suffice. ${ }^{67}$

Scholars continue to debate the extent to which this colonial education was progressive, as well as, more recently, how Filipinos shaped and abrogated United States' educational policy. ${ }^{68}$ The schools' curriculum emphasised vocational and industrial education, on the model of Hampton and Tuskegee Institutes in the United States, schools that, not coincidentally, also served racialised "others." 69 But such institutions met demands for educational reform within the Philippines, dating to the 1870s and 1880s, when nationalists called for free secular schools "including both vocational and technical education and physical education."70 Schools prepared both civil servants and a professionalised middle class, that is a "Filipinised" government bureaucracy and a modernised, Americanised society in the Philippines. ${ }^{71}$

The new federal system dramatically expanded educational opportunities for Filipinas in particular. Before the United States' occupation, Filipina intellectuals like Graciano Lopez Jaena had begun to call for expanded education for women, so that women might also contribute to national life and independence. The

\footnotetext{
66 Justice, "Education at the end of a gun," p. 41.

67 Alexander A. Calata, "The role of education in Americanizing Filipinos," in Mixed Blessing: The Impact of the American Colonial Experience on Politics and Society in the Philippines, ed. Hazel McFerson, Westport CT: Greenwood Press, 2002, pp. 89-97, p. 91.

68 Justice, "Education at the end of a gun," pp. 21-22. A pioneering work that explored the place of public education within federal policy in the Philippines is John Morgan Gates, Schoolbooks and Krags: The United States Army in the Philippines, Westport CT: Greenwood Press, 1973.

69 Glenn Anthony May, Social Engineering in the Philippines: The Aims, Execution, and Impact of American Colonial Policy, 1900-1913, Westport CT: Greenwood Press, 1980, pp. 124-25, cited in Justice, "Education at the end of a gun," p. 45.

70 David E. Gardinier and Josefina Z. Sevilla-Gardinier, "Rosa Sevilla de Alvero and the Instituto de Mujeres of Manila," Philippine Studies 37(1) (1989): 29-51, p. 36.

71 Vince Boudreau, "Methods of domination and modes of resistance: the U.S. Colonial State and Philippine mobilization in comparative perspective," in The American Colonial State in the Philippines: Global Perspectives, ed. Julian Go and Anne L. Foster, Durham: Duke University Press, 2003, pp. 256-90, p. 266. Higher education played a role in this as well; an act of the legislature established the University of the Philippines in 1908, with colleges in Agriculture, Arts, Engineering, Fine Arts, Law, Medicine and Veterinary Science. See Roces, "Women in Philippine politics and society," p. 179.
} 
few advanced institutions open to Filipina women as of 1898 were Catholic schools and newer normal schools for women, established by the Spanish colonial government in the late nineteenth century. These were largely limited to the élite classes in urban areas, and a total of only about a thousand women graduated from the normal schools in the thirty years before 1898. Even for the wealthy, women had no other options for higher learning; only the sons of élite families went abroad for education. ${ }^{72}$ United States' policies opened law, medicine, journalism and other professions to Filipinas for the first time. Boys and girls followed the same curriculum except for the varied skills they learned through industrial work (such as woodwork vs. lace-making). ${ }^{73}$ Although the American schools did not explicitly encourage sexual equality, the new education prepared native-born women for respectable, stable, well paid work in nursing and teaching, and a chance of upward economic mobility. ${ }^{74}$ In the province of Misamis, the United States government employed 155 Filipino men and 119 Filipina women teachers, who greatly outnumbered the American teachers. ${ }^{75}$ Thus nationalist intellectual Ramona Tirona praised the "wider possibilities" that the United States had opened to her and other Filipinas, vocations apart from that of wife or Catholic nun. Now, a modern Filipina "studies medicine, pharmacy, nursing, and even law with a zealous interest; and recently she is venturing into the study of journalism and engineering with unhesitating steps." 76

Protestant missions in the Philippines saw themselves as partners of the federal government in education, filling in the religious components missing from a secular system. With respect to Filipinas, they established a range of institutions for female students. The many mission schools already educating thousands of girls in Japan, China, India and elsewhere, often emphasised domestic science, or perhaps preparation for teaching and secretarial studies, rather than "training as missionaries." 77 In the Philippines, some schools did have women as religious

72 Gardinier and Sevilla-Gardinier, "Rosa Sevilla de Alvero and the Instituto de Mujeres of Manila," pp. 33-35.

73 Sobritchea, "American colonial education and its impact on the status of Filipino women," p. 86.

74 Ibid., p. 79. "Felipa de la Peña and two other Filipino nurses were graduated in August 1909. They were the pioneer nurses in the Islands." See Amelia Pott Klein, "Nursing experiences in the Philippines," Woman's Work 25(7) (1910): 147-49, p. 149.

75 Census of the Philippine Islands 1918, vol. IV, part II, Manila: Bureau of Printing, 1921, p. 200.

76 Tirona, “The Filipino woman," pp. 3, 5. See also Choi, Gender and Mission Encounters in Korea, p. 7. As in Korea (but not China and Japan), the majority of professional women, New Women, feminists were Christian, but in the Philippines these women were both Protestant and Catholic, and not necessarily a product of missions or mission schools.

77 R. Pierce Beaver, American Protestant Women in World Mission, Grand Rapids, MI: William B. Eerdmans Publishing Co., 1980, p. 121. The Methodist women's missionary society and the Women's American Baptist Home Mission Society, for example, ran "numerous schools" of the less ambitious sort in Cuba, and almost all Anglican schools in Africa (even the "higher" boarding schools) stressed domestic training for girls. Jason M. Yaremko, "'The path of progress': Protestant missions, education, and U.S. hegemony in the 'New Cuba,' 1898-1940," in American Post-Conflict Educational Reform: From the Spanish-American War to Iraq, ed. Noah 
leaders in mind. With the support of the Women's Foreign Missionary Society of the Methodist Episcopal Church, Winifred Spaulding founded the Harris School (later Harris Memorial College) in Manila in 1903. ${ }^{78}$ Spaulding was herself a deaconess who had been Superintendent of Fisk Bible and Training School in Kansas City, and specialised in nursing deaconesses. Presbyterian missionaries founded Ellinwood, another Bible school for girls in Manila, along with a Boys' Dormitory to meet what they perceived as local needs. ${ }^{79}$

The American Board established what was perhaps the most ambitious school for Bible women in Cagayan in 1923. Its founder, Isabel Fox, had visited several Bible schools on her journey from the United States to take up her missionary post in the Philippines: the Union Bible School in Yokohama, the Evangelistic School in Kobe, and Ellinwood and Harris in Manila.$^{80}$ Building on all of these examples, Fox conceived of a school for women in Mindanao with a rigorous three-year curriculum. Its graduates would become Bible women and constitute a vanguard to spread the gospel among their people. Someday the institution might even become a women's college. The Woman's Board embraced Fox's vision with an exceptionally large disbursal of $\$ 13,000$ in 1923 from the estate of an older member of the Woman's Board. Ellen Carruth's legacy enabled the construction of a building to serve as a Bible Training School and an enlarged girls' dormitory. ${ }^{81}$

The modern education provided by Carruth Bible School included "new ideas of sanitation and hygiene" along with "the ideal of a strong, pure, Christian girlhood" to lay the groundwork for "Christian motherhood" and a strong church. Such an education aimed to "transform the home, and best of all, transform the life." ${ }^{82}$ Consequently, Christian study of Scripture shared space on the curriculum with practical education and liberal arts and sciences. "A practical

Sobe, NY: Palgrave Macmillan, 2009, pp. 53-74, p. 68; Modupe Labode, “From heathen kraal to Christian home: Anglican mission education and African Christian girls, 1850-1900," in Women and Missions: Past and Present, Anthropological and Historical Perceptions, ed. Fiona Bowie, Deborah Kirkwood and Shirley Ardener, Providence, RI: Berg, 1993, pp. 126-44.

78 Spaulding led the school from 1901 to 1903; in 1904 it was renamed the Kansas City National Training School for Deaconesses and Missionaries.

79 "Everything seems to indicate that the kind of school needed here is a Bible school." See "Educational branch of the Philippines mission," Woman's Work 22(7) (1907): 157. Ellinwood was founded in 1899 and Union in 1907.

80 "Miss Anna Isabel Fox, our new missionary to the Philippines, writes from Cagayan," Light and Life for Woman, 49(1) (January 1919): 35-38, p. 35.

81 Kate Lamson to Evelyn Fox, 8 October 1923, ABC 17.9.2. Ellen Carruth was an officer of the Woman's Board for 23 years, first as assistant treasurer then treasurer. The funding of this school was an exceptional event; as of 1925, the Woman's Board (of the American Board of Commissioners for Foreign Missions) supported 29 girls' boarding schools, 300 day schools, and 20 kindergartens; but it sponsored only one other training school for Bible women. See Kate G. Lamson, "History of the Woman's Board for Missions," typescript manuscript, 1927-28, p. 85, ABC 88.

82 Marian Wells Woodward, "Conditions among the Filipina women," Light and Life for Woman 48(5) (May 1918): 211. 
course of home nursing" for all Bible women would enable them to "help in the homes they enter," planned Isabel Fox, incorporating an idea already in place at the Methodist Deaconess Training School in Manila, which Fox had visited upon her arrival in the Philippines. ${ }^{83}$ The senior Bible scholars gained experience volunteering in the mission hospital. ${ }^{84}$ Their "practical" instruction centred on medical knowledge, from nursing to "ventilation and sanitation" 85 but also included domestic science and gardening. ${ }^{86}$ In addition, they studied health sciences (including obstetrics), sociology, English and history in conjunction with the Bible. Music instruction included piano, organ and choral singing. Composition, reading, psychology and pedagogy rounded out a course of study designed "to develop ... independence of thought and action." ${ }^{87}$

While some American women missionaries like the Foxes envisioned Filipinas as evangelists in their own image, others saw female students primarily as future pastors' wives. Filipinas' experiences at Harris, Ellinwood and Carruth Bible Schools thus differed from what they could expect at Union Theological Seminary (1904) in Manila, where the emphasis was on producing male Filipino pastors. ${ }^{88}$ In 1921, Congregationalists and Presbyterians in Dumaguete opened the Silliman Bible School, which became co-educational in 1924 mostly by taking in the wives of its male students. ${ }^{89}$ Meanwhile, Jaro Industrial School in Iloilo City, founded for boys in 1905 by Baptist missionaries, began accepting girls in 1913 for vocational preparation. The curriculum was relatively limited at the Women's Bible Training School at Jaro, but even there included nursing and religious music. One needed more than study of the Bible, founder Anna Johnson explained, to bring others "to a knowledge of the living God." 90

Filipinas saw an advantage to such diverse instruction. For example, training in both teaching and hospital work was popular, no doubt for pragmatic reasons. ${ }^{91}$ The missions themselves might employ the women they had educated; Josefa Esteban became the office secretary at Ellinwood upon finishing her degree

\footnotetext{
83 Anna Isabel Fox, "Summer work at Cagayan," Light and Life for Woman 42(9) (September 1922): 322-24, p. 323; "Miss Anna Isabel Fox, our new missionary to the Philippines, writes from Cagayan," p. 35.

84 Floyd O. Smith, "Philippine Mission of the ABCFM Mission Hospital, Cagayan, Misamis. Annual Report 1924," 1925, АBC 17.9.2.

85 Florence Fox to Kate Lamson, 5 May 1921, ABC 17.9.2.

86 Mrs F.C. Laubach, “Our new Philippine task,” Light and Life for Woman 48(6) (June 1918): 251-54, p. 251.

87 Evelyn Fox to Kate Lamson, 4 November 1923, ABC 17.9.1.

88 Run cooperatively by Baptists, Congregationalists, Disciples of Christ, United Brethren, Methodists and Presbyterians, Union Seminary employed female teachers, including Ella Laubach. See Herbert E.B. Case, "History of the Philippine Mission, 1911-1942," typescript manuscript, p. 11, ABCFM 88.

89 The decision to admit women to Silliman indirectly led to the closure of the Carruth Bible School.

90 Belo, “Anna V. Johnson," p. 287; Anna V. Johnson, “In training at Jaro," Helping Hand (1909): 14-15.

91 "Field Correspondents / Miss Florence Fox writes from Cagayan, Philippine Islands," Light and Life for Woman 52(10) (October 1922): 365-68, p. 369.
} 
there in $1921 .^{92}$ Others put their experience and knowledge to use elsewhere. Training in singing, fitted girls from Cebu for "increasing demand ... at school and outside functions." ${ }^{\prime \prime 3}$ And those with a deep religious calling could begin the work of Bible women and deaconesses even as students by teaching, leading open-air prayer meetings and "sing[ing] the Gospel message" in the villages. ${ }^{94}$ Congregationalist Bible students in Mindanao had charge of nine Sunday schools in 1922; in each one, as many as sixty-four children and adults would take up uncomfortable seats - "merely bamboo poles laid across stakes driven into the ground" - in the shade. ${ }^{95}$

\section{Dormitories and athletics}

Missions provided Filipinas with expanded access to education in another way besides direct instruction. "Dormitory work," as the missionaries termed it, represented an accommodation to local populations. Filipinos generally looked with favour on the expanded system of public schools under American occupation. Yet the distance, especially to a provincial high school, could be great, taking over a day's travel in each direction. In addition, some Filipino families ("Moros," or Muslims, in particular, who dominated in the south) were reluctant to send their daughters to school with boys. ${ }^{96}$ This partly explains the low number of women who finished university degrees in the first two decades of United States' rule; only twelve women graduated from the University of the Philippines between 1880 and 1920.

The mission-run single-sex dormitory developed in response to this situation. A girls' dormitory appealed to Filipino parents as a protected space to board their daughters near schools with no suitable housing. Older unmarried women also chose to live in dormitories while completing upper level programs. In this way, missions brought the new system of public education within reach of the local population. For example, the dormitory in Cagayan made the local public high school an attractive prospect to areas some distance away, such as the strongly Catholic town of Mambajao, a "lovely spot" on a volcanic island, over a day's journey from the mission. Girls might come from Mambajao to Cagayan to be educated, and in turn, "if we can get the school girls into a Christian environment" in the dormitory, its founder Isabel Fox calculated, some might

\footnotetext{
92 Presbyterian Church in the U.S.A., Board of Foreign Missions, Annual Report, 1921, p. 352.

93 Eda C. Bowman, “At the Emerson Dormitory for girls," Woman's Work 34(6) (1919): 131.

94 Presbyterian Church in the U.S.A., Board of Foreign Missions, Annual Report, 1921, p. 352.

95 A. Isabel Fox to Kate Lamson, 19 October 1922, ABCM 17.9.2.

96 Effa Laubach to Kate Lamson (Foreign Secretary of the Woman's Board), 28 May 1918, ABC 17.9.2. Also see Effa Laubach, Light and Life for Woman 48(9) (September 1918): 374-77, p. 374.
} 
eventually become Bible students. ${ }^{97}$ The dormitory proved a successful venture; Fox herself found it a surprisingly easy and "splendid opportunity for doing personal work." ${ }^{\prime 98}$

For missionaries, then, dormitories responded to a need in the community and brought possible converts into proximity with the missionaries. Further, they envisioned the dormitory itself as a self-supporting enterprise that would serve as a Christian home, supplementing and completing the girls' education. The very architecture of the dormitory at Cagayan evoked American Protestantism; the building was "very much of a New England type," with large windows and a "gray and white exterior." 99 The dormitory could inculcate certain moral and religious values in young Filipinas - requiring, for example, that prayers would be said morning and night, and Bible verses and hymns learned. Yet its identity as a refuge and home was always central. In appealing for funds to support the enterprise, the Woman's Board periodical Life and Light emphasised the "proper protection" and "personal care" that Miss Fox would take of the girls, and that the dormitory represented an "enlarge[ment] of the borders of her home." 100 The magazine subsequently captioned a photo as "Miss Fox and Her Family of Girls." The metaphor was not entirely misplaced since Isabel referred to residents as "a family of my own." ${ }^{101}$ Indeed, Fox appeared more as a matron than a teacherironically assuming a more domestic role in order to support Filipinas' nascent professionalism.

From the creation of a domestic female space - so seemingly old-fashionedthe dormitories served as a starting place for modernisation and emancipation much as the female spaces of settlement houses and women's clubs had done for American women. By improving home conditions among Filipinos, missions would augment the work of public schools "to enlighten the present generation," Marian Wells Woodward commented. ${ }^{102}$ "Aside from giving these girls ... a good home and proper care and chaperonage," as Filipino families sought, dormitories taught them modern ideas about sanitation, Evelyn Fox reported. ${ }^{103}$

Filipina dormitory residents likewise were not confined to the domestic roles that would have ordered their lives with their families. The dormitory offered

\footnotetext{
97 Anna Isabel Fox, “Touring in tropical seas," Light and Life for Woman 52(10) (October 1922): 365-68, p. 365.

98 "Field Correspondents: Miss Anna Isabel Fox writes from Cagayan Station, P.I.," Light and Life for Woman 50(2) (February 1920): 72-75, p. 72.

99 Evelyn Fox to Mabel Emerson, 24 September 1926, ABC 17.9.2.

100 Kate G. Lamson, “Editorials: another open door," Light and Life for Woman 49(8) (September 1919):

360-61, p. 360.

101 "Field Correspondents: Miss Anna Isabel Fox writes from Cagayan Station, P.I.," p. 73.

102 Woodward, "Conditions among the Filipina women," p. 211.

103 Report of Fourth Year of Girls' Dormitory [1923], Documents and Reports, ABC 17.9.2.
} 
opportunities for Filipina women's leadership. The girls oversaw the Cagayan Dormitory through a Student Assembly and Student Council. Girls at other dormitories and schools likewise organised self-government with the approval of the mission. ${ }^{104}$ In fact, missionaries saw the dormitory as a field for Bible School students to exert their Christian influence. ${ }^{105}$ The mission station at Cagayan soon began requesting increasing funds to pay salaries to Isabel Maandig and Julia Yapsutco as "native assistants" in the school and dormitory. Evelyn Fox wished eventually to hand over leadership to one of these women, or to an unnamed third Filipina, "a young married woman, of such a beautiful nature, and with eight years $[\mathrm{sic}]$ experience in primary teaching." Fox urged the Board to provide these women with additional professional training, in the new Normal School in Manila or in the United States. ${ }^{106}$

By its fourth year, the Cagayan dormitory also accommodated Filipinas' enthusiasm for a very "modern" feminine pursuit: competitive athletics sports. Baseball, basketball and other sports were unknown to Filipinas prior to American occupation. ${ }^{107}$ Now these pursuits became part of a modern vision of femininity. The enthusiasm for girls' baseball matched the contemporary celebration of physical vitality and recreational sports among American women. For Filipinas and Americans alike, athletics denoted a modern, active womanhood. "Muscular Christianity" was not utterly restricted to men anymore; in the 1920s, it proved expansive enough to enfold all youth, even girls. ${ }^{108}$

Athletic teams were organised by public schools at the local level, arranged into associations by the Director of Education, and toured for competitions. Mission schools too developed athletic programs for girls. The Ellinwood School in Manila offered female students calisthenics and indoor baseball. "We have some very good players," boasted Julia Mott Hodge, reporting on how the team had won its first match. ${ }^{109}$ The players themselves showed quiet pride in their accomplishments. The ten fourteen- or fifteen-year-old girls on the baseball team from Oroquieta won over their parents' misgivings at participating in

\footnotetext{
104 Bowman, "At the Emerson Dormitory for girls," p. 131.

105 Evelyn Fox to Kate Lamson, 19 May 1924, ABC 17.9.2.

106 Evelyn Fox to Mabel Emerson, 18 October 1926, ABC 17.9.2.

107 Janice A. Beran, “Americans in the Philippines: imperialism or progress through sport?" International Journal of the History of Sport 6(1) (1989): 62-87.

108 On muscular Christianity, see: Donald Hall (ed.), Muscular Christianity: Embodying the Victorian Age, Cambridge: Cambridge University Press, 1994; Robert Higgs, God in the Stadium: Sports and Religion in America, Lexington: University Press of Kentucky, 1995; Tony Ladd and James Mathisen, Muscular Christianity: Evangelical Protestants and the Development of American Sport, Grand Rapids, MI: Baker Books, 1999; David I. Macleod, Building Character in the American Boy: The Boy Scouts, YMCA and Their Forerunners, 1870-1920, Madison: University of Wisconsin Press, 1983; Nina Mjagkij and Margaret Spratt (eds), Men and Women Adrift: The YMCA and the YWCA in the City, NY: New York University Press, 1997; Clifford Putney, Muscular Christianity: Manhood and Sports in Protestant America, 1880-1920, Cambridge MA: Harvard University Press, 2001.

109 Presbyterian Church in the U.S.A., Board of Foreign Missions, Annual Report 82-83 (1919): 338.
} 
the championship in Manila; their fast pitching and strong hitting astonished the crowd. They proceeded to win the title and carry the banner back home. "Everybody said when they saw it, 'We all knew that Mindanao would someday be the greatest island of them all, but we did not suppose it would begin with baseball."" The missionaries praised their home team for being so "healthy, and strong, and ... practic[ing] very, very faithfully," without indulging in "too many sweets." Their mothers "were as proud of their baseball daughters as they could be."110

While the American Board's mission at Cagayan did not directly organise girls' athletics, its dormitory hosted visiting athletic teams, especially girls' baseball teams. Inter-provincial athletic meets filled Carruth Memorial Hall beyond its capacity once or twice each year in the 1920s; with many of the visiting teams as their guests, missionaries lacked enough bedding. "The class room, ironing room, and sala will be sacrificed for bedrooms during this invasion," wrote Isabel Fox to the Board. Cots filled the Bible Class room. "This made a great deal of confusion but we think it paid and made us more friends."111

Like the dormitory work in general, missionaries saw an advantage to hosting young female athletes: gathering young Filipinas where they might come under religious influence. Baseball itself could be played in a Christian manner. For example, the champion Oroquieta team invited girls from Bukidnon, a town in the mountains, to play against them. The Bukidnon girls were astonishingly young, "so little and so thin," and used to the cool temperatures of a higher altitude. "Of course the other teams beat them as we all expected," reported Effie Laubach.

But the surprise came for us when Oroquieta played them. I saw the girls whispering around about something, but did not know what they planned. I found out when they played the game. They mixed their team all up and put the poorest player they had in as pitcher. The little Bukidnon girls found they could hit her slow balls all the way over the Oroquieta heads. ${ }^{112}$

Oroquieta entered the last inning one run behind-and a ten-year-old from Bukidnon caught a foul ball, to finish the game. "Bukidnon had won! The people could hardly cheer for laughing. They crowded around and praised the little girls for beating the champions of the Philippines. But the team that praised them the most was the Oroquieta team they had beaten. Think what it meant." Then the Oroquieta team taught them some Christian songs, and "some

110 Effa L. Laubach, "Junior department / girl champions of the Philippines," Light and Life for Woman 50(10) (Oct. 1920): 463-69, pp. 464-67.

111 Report of Fourth Year of Girls' Dormitory (1923), ABC 17.9.2.

112 Laubach, "Junior department / girl champions of the Philippines," pp. 468-69. 
of those little mountain girls heard the name of Jesus for the first time.... To this day we hear them singing the songs they learned at our house, when we go back among the mountains. And some of those girls we entertained then have since become sweet Christians." ${ }^{\prime 13}$ The most powerful testament to the Oroquieta team's religious faith was not only how they practised Christian virtue but the fact that they acted on their own initiative. They had completely absorbed and understood the spiritual lessons of "dormitory work" - and those lessons were entirely compatible with athletic talent.

Missionaries did not perceive any serious resistance in their students and dormitory residents. The worst reported at Cagayan were "small fuss[es]," "liveliness," pranks and "naughty things." ${ }^{114}$ There is no record of anything so overt or organised as the "revolt" of South African girls against doing eight hours of laundry per day at their mission school. ${ }^{115}$ Filipinos and Filipinas were undoubtedly capable of dissent and revolt; the 1,500 parishioners who left the Methodist Episcopal Church with their pastor, Nicolas Zamora, in 1906, certainly included women. "The immediate cause seems to have been unequal treatment accorded Filipino pastors" - the "smug young men," as Zamora called them in a newspaper interview, "who place their national prejudices above the teachings of Jesus Christ [and] belittle our capabilities." 116 Why is rebellion missing from the mission archive? Was it a deciding factor that missionaries recognised Filipinos' needs and adapted to their aspirations (secular as well as religious)? Or is this silence a natural result of the voluntary nature of Filipina participation in Bible training and dormitory life? Filipinas could always persist in indigenous customs and traditions, with Catholicism, Islam and animism remaining strong throughout the islands.

\section{The politics of dress}

Filipinas' embrace of the modern womanhood that American missionary women offered and modelled - through religious leadership, preparation for the professions, athletics and participation in public life - can be difficult to separate from assimilation. Yet dress and material culture most strongly suggest that in seeking and valuing a modern revision of femininity, they were not simply acquiescing to Americanisation.

\footnotetext{
113 Ibid. See photographic illustration, "The champion team."

114 Isabel Fox to Kate Lamson, 29 August 1921 and 8 April 1921, ABC 17.9.2.

115 The laundry rebellion took place in 1877. Labode comments that "Revolts [by indigenous people] were not rare in missionary institutions" in the nineteenth and twentieth centuries, though they tended to be small in scale. See Labode, "From heathen kraal to Christian home," p. 138.

116 Clymer, "The Methodist response to Philippine nationalism, 1899-1916," Church History 47 (December 1978): 421-33, p. 426.
} 
Consumer culture, fashion and clothing in particular might seem a minor concern to a missionary enterprise. But the missionaries' preoccupation with clothing betrays the extent to which Christianisation and cultural assimilation were intertwined in their minds. In a letter to the home office, Effa Laubach praised a recently baptised Filipina, "one of our stars," for "reading my Ladies Home Journal and know[ing] what the girls in America are doing." 117 Consumer culture set the standards of beauty against which Americans measured Filipinas. As historian Kristin Hoganson observes, "U.S. fashion writing presented the spread of European fashion as an index of civilisation in Asia and the Middle East." Too much constriction or concealment (as with veils) and too much exposure of the body both "clearly called for Western sartorial intervention."118

Clothing could thus be a measure of imperial power and a site of conflict. Missionary women associated modern American aesthetics in dress with comfort, cleanliness and rationality. "My girls are sensible children and prefer simple American clothes as a rule," wrote Isabel Fox. ${ }^{119}$ When faced with indigenous styles, they attempted to reform. Florence Fox judged that, "Filipino clothes are not very practicable," and tried to introduce the use of wraps. ${ }^{120}$ Meanwhile Isabel confessed to a longing, "to do something to their hair. It does look so untidy and uncomfortable." ${ }^{121}$ Home missionaries - supporters in the United States - often sent dolls to distribute to the Filipina girls; these dolls would have implicitly modelled Euro-American styles of dress. Class evidently played a part in who did - or could - adopt the assimilated clothing. "Little high class girls dress in dainty dresses with all the frilly underwear very like her [sic] little American cousin," Isabel observed. By contrast, the poorer "little girls that play about the thatch houses and in the market wear a single colored slip." ${ }^{122}$ The missionaries proudly measured the declining "Moro" practice of staining one's teeth with betel. "They are fast learning the ways of civilisation, and are all proud of their white teeth now." 123 The equation of certain dress and bodily practices with "civilisation" also appears in the contemporary Indian boarding school movement, in which assimilating middle-class American dress, posture and so forth, was seen as a crucial sign of success in overcoming savagery.

\footnotetext{
117 Effa Laubach to Kate Lamson, 28 May 1918, ABC 17.9.2.

118 Kristin Hoganson, "The fashionable world: imagined communities of dress," in After the Imperial Turn: Thinking with and through the Nation, ed. Antoinette Burton, Durham NC: Duke University Press, 2003, pp. 260-78, pp. 268, 273. Also see Roces, "Women in Philippine politics and society," p. 171.

119 Anna Isabel Fox, “My Philippine girls," Light and Life for Woman 51(1) (January 1921): 22.

120 Florence Fox to Kate Lamson, 5 May 1921, ABC 17.9.2.

121 Anna I[sabel] Fox, "A vacation among the Moros," Light and Life for Woman 49(10) (November 1919): 469-71, p. 469.

122 A. Isabel Fox to Kate Lamson, 7 June 1920, ABC 17.9.2.

123 Anna Isabel Fox, "On tour and at home in the Philippines," Life and Light for Woman 52(2) (February 1922): 59-64, p. 63.
} 
American styles of dress were not only taken as a sign of "civilisation" but in certain contexts a marker of modernity and professionalism, particularly in nursing. Florence Fox's nursing uniform (worn for some formal photographs) designated her as a professional, the "superintendent of nursing." Filipinas wore nurses' uniforms too- as students and while working in hospitals. ${ }^{124}$

The mission documents do not record Filipinas' reactions to American clothing, and almost never discuss dress as anything more complicated than cultural superiority and inferiority. "Sometimes I wish we could see ourselves through the eyes of our so-called heathen sisters," mused Isabel Fox in a rare exception. "I wonder if we look as ugly to them as they do to us, if our white teeth and tight complex clothing and pale skin, and hair of all shades of brown seem curious and homely to them." ${ }^{125}$ Filipinas did not necessarily "read" American fashion or bodily practices as American. For example, most young Filipinas wore their hair bobbed with bangs, as did fashionable American women of the 1920s; choosing this style more likely seemed juvenile more than assimilationist. Elements of the "modern girl" style emerged around the world in the 1920s and 1930s, a "global phenomenon" whose many forms owed as much to local conditions as to international film and advertisements. ${ }^{126}$

Even the Filipinas most strongly associated with missions did not consistently choose American styles. Here the visual records speak to what the written documents omit. The Filipina women students at the Carruth Bible School wore with pride either American or Filipina dress; a formal photograph, probably of the graduating class of Bible scholars, shows three of the four Filipinas wearing the beautiful, elaborate terno (or "butterfly dress"), which had evolved in recent decades. ${ }^{127}$ This was no traditional "native costume" but the height of fashion and modernity from the Filipina perspective. The terno became the favourite public attire of Filipina women suffragists in the 1920s and 1930s. Though it developed and became popular in the period of American colonisation, it did not derive its elements from American styles. Rather, the terno (sometimes also called mestiza dress) combined the Spanish-influenced camisa and saya. ${ }^{128}$ The butterfly sleeves were particularly distinctive from contemporary EuroAmerican evening wear. ${ }^{129}$ It evoked Filipino nationalism and, simultaneously,

\footnotetext{
124 All the personnel - nurses and attendants - who worked with Fox were Filipino and about half were women. See Smith, "Philippine mission of the ABCFM Mission Hospital."

125 Fox, “A vacation among the Moros," p. 469.

126 The Modern Girl around the World Research Group, The Modern Girl around the World: Consumption, Modernity, and Globalization, Durham NC: Duke University Press, 2008.

127 Paul Rodell, Culture and Customs of the Philippines, Westport CT: Greenwood Press, 2002, p. 113.

128 The girls' school uniforms at Harris Memorial Deaconess Training School comprised a blue cotton skirt and a white cotton camisa, "which is the stiff transparent jacket the Filipina women wear." Norma Waterbury Thomas, Jack and Janet in the Philippines, West Medford MA: Central Committee on the United States Study of Foreign Missions, 1918, p. 42.

129 Rodell, Culture and Customs of the Philippines, p. 113.
} 
femininity. It made a visual argument for Filipino sovereignty by making women into symbols of nationalism. Notably, the terno did not really position women as bearers of tradition, since it was a newly invented style. Unlike nationalist movements in other places, which privileged folkloric dress for women, the terno signalled modernity along with sovereignty.

It is striking to see Bible women in training choose such subtly but undeniably politicised clothing. Filipina "new women" wore the terno strategically as they laid claim to the public sphere; its nationalist meanings gave legitimacy to women's presence there. Thus suffragist (and beauty queen) Pura Villanueva Kalaw praised her contemporary, María Paz Mendoza-Guazon, for her accomplishments as the first Filipina woman physician, for her active participation in the women's suffrage movement, and - in the same breath - for "her elegant crimson Filipino terno." 130 The terno connected women professionals, clubwomen, beauty queens and suffragists, making suffragists seem less radical, and beauty queens more progressive. ${ }^{131}$ Its use on ceremonial occasions was respectable and not uncommon. A photograph from the 1930s shows all the girls at the Silliman Elementary School wearing the balintawak (a less formal version of the terno, also with butterfly sleeves) to march in the Founders' Day parade. ${ }^{132}$

Most intriguingly, photographs show American missionary women in the Filipino terno. In a series of such images from Cagayan, the Fox sisters wear ternos at an unnamed special occasion, perhaps a wedding, perhaps of a Filipina Bible woman. In other photographs, American and Filipina women pose formally together in butterfly sleeves. Isabel Fox referred to "a picture of us all in our native dress" (emphasis added), meaning her with eight Bible scholars. ${ }^{133}$ In 1916, the Pearl of the Orient (the newsletter of the American Baptist Foreign Mission Society, published in the Philippines) featured a photograph of the second graduating class of the Bible Training School at Jaro. In it, the seven women and their teacher, Anna V. Johnson, are all wearing "long flowing gowns" and "panuelo." 134

130 Pura Villaneuva Kalaw, "Introduction," in María Paz Mendoza-Guazon, The Development and Progress of the Filipino Women, Manila: Bureau of Printing, 1928, n.p.

131 See Mina Roces, "Gender, nation and the politics of dress in twentieth-century Philippines," Gender and History 17(2) (2005): 354-77.

132 Undated photo, “Edith Adele McKinley, age 8 years," ABC 78.1, Box 29; “McKinley, James F. and family." ABC 78.1.

133 A. Isabel Fox to Kate Lamson, 12 October 1920, ABCFM 17.9.2. Filipino culture infiltrated the American Board's mission station in other subtle ways as well. For example, the dormitory "Carruth Hall" had a salareferred to as such by the missionaries themselves in private correspondence. Remarkably they did not call this room for relaxation and study a "parlour" (which would have sounded horribly Victorian by the 1920s). Caption of photo \#15, once part of a scrapbook; picture collection: Missions, Box 20, folder 4: Cagayan, ABC78.20.

134 Perla D. Belo, “Anna V. Johnson: Missionary Pioneer, Educator, and Evangelist," American Baptist Quarterly 12 (1993): 289. 
The mission records that remain do not comment on the thinking behind this choice of dress. While Americans often perceived of foreign attire as appealingly "exotic," regarding their adoption of it as just imperialist appropriation, Filipino culture is an insufficient explanation. It is also difficult to imagine that the American missionaries wore ternos as public advocacy of Filipino independence. Perhaps it expressed a less political sort of solidarity. The same American women who at times condemned Filipina women's dress, at other times admired it. Though she disapproved of their hairstyles, Isabel Fox praised Moro women's "sorong" as "very modest."135 At times, cultural distinctions blurred in the missionaries' eyes. When nine Bible women came to a meeting, Isabel noted "their simple home dresses" without further description-reading neither savagery nor civility in their style. ${ }^{136}$ Even as missionaries strove to "modernise" Filipinas, they were attracted to traditional Filipino culture. Supporters back home urged them to send examples of native handicrafts, for use in building interest and raising funds among American audiences. Most commonly, the Board asked for locally made lace, piña fabric (made from pineapple fibre) and examples of indigenous "costumes." ${ }^{137}$ This keen interest from "home" legitimised missionary women not only in collecting, but wearing, local dress (the butterfly dress, or terno), habits which would seem to be the antithesis of assimilation and Americanisation.

But most pointedly (at least for me), the resplendent silk terno that Evelyn Fox wears with such joy in her studio portrait was a gift from her students. "The beautiful golden costume was given me by my girls in my Bible Class last January," reads her note on the back of the image. ${ }^{138}$ Fox did not insert herself into Filipino symbology; her students invited her in. Filipinas sought to share this part of modern womanhood so distinctively their own (Figure 32).

\footnotetext{
135 Anna I[sabel] Fox, "A vacation among the Moros," Light and Life for Woman 49(10) (November 1919): 469-71, p. 496.

136 Anna Isabel Fox, “Field Correspondents," Light and Life for Woman 52(5) (May 1922): 197.

137 Rodell, Culture and Customs of the Philippines, p. 113 mentions this economic dimension; American colonial officials tried to nurture the domestic production of local fabrics to cultivate self-sufficiency.

138 Photograph, “Grace E. Fox," box 15, ABC78.1.
} 


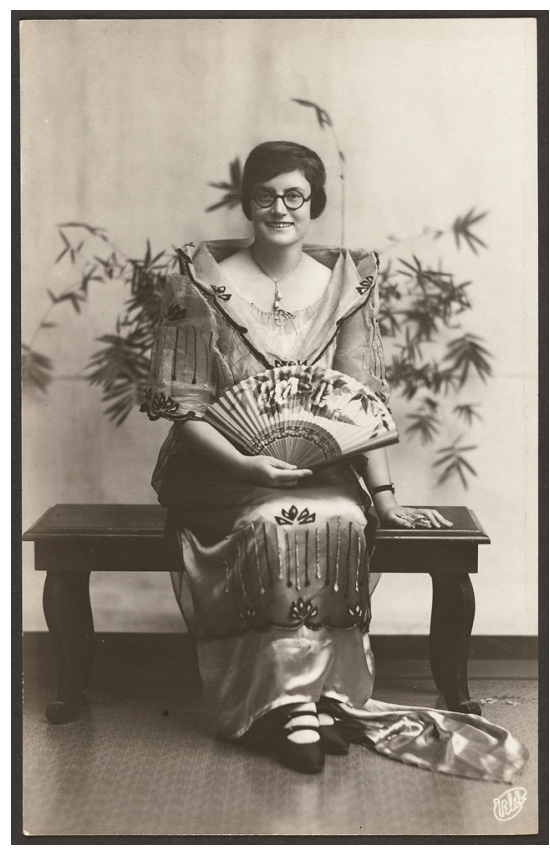

Figure 32. Grace Evelyn Fox, “The beautiful costume was given me by my girls..."

Source: By permission of Wider Church Ministries, United Church of Christ and Houghton Library, Harvard University (ABC78, box 15, folder "Fox, Grace E.").

\section{Conclusion}

Colonial archives marginalise colonial subjects without being able to efface them. A consideration of Bible women, dormitory work, athletics and dress demonstrates two important, yet overlooked, facets of the effects of imperialism on culture. First, Filipina womanhood was not a wholesale American import. The "nearly 7000 in classes, including 600 women and girls" that the mission gathered by $1930,{ }^{139}$ did not simply assimilate and Americanise as the missionaries (and other American colonial agents) may have desired. Under Spanish rule, higher education and the professions were closed to women; women did not participate in sports, and chaperonage and early marriage curtailed women's "public" activities of all sorts. Their involvement in United States' missions, as Bible women or dormitory residents, helped Filipinas to forge new paths. But

139 Herbert Case, “ABCFM History, 1910-1943," typescript, ABC88, p. 9. 
whatever their devotion to the Bible and however strong their enthusiasm for baseball, Filipinas defined modern womanhood in their own ways. Butterfly sleeves rejected American interference in symbolic and highly visible terms.

Second, American women missionaries themselves were susceptible to influence from the culture surrounding them and the individuals with whom they had personal relationships. This fascination, however irregular and unequal, unsettled the very definitions of gender roles, savagery and civilisation that the missionaries had brought with them. As historians of empire have been starting to show, imperialism affected imperialists as well as their subjects. The contradictions within ideas of gender, of modernity, of imperialism itself open up a more complicated story than the official narrative ever openly acknowledged.

\section{Acknowledgements}

I would like to thank the participants at the Paradoxes of Domesticity conference, especially its conveners Hyaeweol Choi and Margaret Jolly, for their warm collegiality and intellectual generosity as I wrote and revised this paper. 
This text taken from Divine Domesticities: Christian paradoxes in Asia and the Pacific, edited by Hyaeweol Choi and Margaret Jolly, published 2014 by ANU Press, The Australian National University, Canberra, Australia. 